\title{
Research can help desert growers in an era of water constraints
}

W.R. GOMES

Vice President

Agriculture and Natural Resources ess than a century ago, only the most drought tolerant plants survived in the desert valleys of southeastern California. Annual rainfall of three inches or less supported only such denizens as creosote, mesquite, screw bean and saltbush. But diversion of Colorado River water beginning in the early 1900 s transformed the landscape. A 1927 Imperial County brochure described the region as "America's winter garden."

Today these valleys, along with the contiguous growing area in Arizona, make a unique contribution to the nation's dinner tables - producing virtually the entire winter supply of head and leaf lettuces, broccoli and cauliflower.

In this issue of California Agriculture, we look at the promise - and the challenge - of desert agriculture, the 675,000 productive acres in the Imperial, Coachella, Bard and Palo Verde valleys which annually contribute more than $\$ 1$ billion to the state's economy.

Many believe desert agriculture is on the brink of economic expansion, as domestic and international markets for food and fiber grow (see page 12), and prime farmland in other parts of the state succumbs to development. Several factors provide a competitive advantage to desert producers: relatively inexpensive water from the Colorado River water, a year-round growing season and soil enriched by alluvial deposits from the Colorado River.

But there are challenges as well, the traditional ones such as devastating pest populations which often flourish in yearround production systems - and the new ones, such as the increasing need to conserve water as Southern California is pressured to live within its original Colorado River water entitlement (see page 6).

Within California, desert growers have first priority for use of Colorado River water for agricultural purposes. But as urban areas in the Southwest grow, and the seven states using Colorado River water take close to their full allocations, there is increasing pressure on all Southern California consumers to conserve. For instance, for the second time in December 1996, the Bureau of Reclamation refused the Imperial Irrigation District's request for water; the district subsequently submitted a reduced request.

Desert growers also must continue to use a water source which is high in salts. Salt balances in the crop root zone must be managed on a continuing basis to prevent productivity losses. When farmers use additional water to flush salts through the soil, salt laden drainage flows through a tile system to the Salton Sea. The Sea is now more than $30 \%$ saltier than the Pacific Ocean; its salinity and pollution may have contributed to several die-offs of thousands of birds (see page 8).
Various stakeholders have proposed solutions to this environmental dilemma, varying in expense and feasibility. These range from a diking operation which would concentrate salts in one area of evaporation ponds, to a proposal to build a pipeline to the Gulf of California and circulate water from the Sea of Cortez through the Salton Sea. A measure to mitigate impact on wildlife would be to use agricultural wastewater to create new wetlands, which would serve both as habitat and as a biological filter to partially treat the wastewater.

Historically, the partnership of UC scientists with desert growers has solved daunting problems, including the development of a seed testing program which eliminated lettuce mosaic virus as a major threat to the country's lettuce industry, and last year, a risk assessment of Karnal bunt in desert wheat which led to a lifting of a federal quarantine (see page 29). Continuing efforts are aimed at management of the silverleaf whitefly, a devastating pest (see page 25).

Agriculture has flourished through this partnership. In the future, as growers cope with increasing water competition, particularly in drought years, their teamwork with UC scientists will again be critical. For instance, UC research has shown that water transfers and water marketing can offer flexibility for reallocating water when resources are scarce. UC scientists analyzed the effects of the state water bank during the drought period of 1987 to 1992, and found that farmers are prepared to sell water on a short-term basis if they receive adequate compensation and if they are guaranteed they won't lose their water rights in the future. Compensating growers for crop fallowing or partial fallowing is one alternative that may be useful in drought years.

UC water scientists are determining how to optimally apply water to minimize drainage impacts while maintaining crop yield. Future UC research should help answer questions in several disciplines. For instance, agronomists should learn the effects of drought stress and the impacts of crop fallowing or partial fallowing on field crops such as alfalfa. Economists and sociologists should investigate the impact of crop fallowing on rural economies. Soil and water scientists should further explore possible reclamation of polluted and saline waters in areas like the Salton Sea Wildlife Refuge.

By pursuing this research with our partners in industry, the Division can support the state's economy, and help all water users adjust to future pressures. We can make existing supplies more flexible to meet critical needs in drought years and better satisfy the increasing demands on finite water resources. 